\title{
Comparative description of the immature stages of two very similar leaf footed bugs, Holymenia clavigera (Herbst) and Anisoscelis foliacea marginella (Dallas) (Hemiptera, Coreidae, Anisoscelini)
}

\author{
Daniela Rodrigues ${ }^{1} \&$ Gilson R. P. Moreira ${ }^{1,2}$
}

\author{
${ }^{1}$ Programa de Pós-Graduação em Biologia Animal \\ ${ }^{2}$ Departamento de Zoologia, Instituto de Biociências, UFRGS. Av. Bento Gonçalves, 9500, Bloco IV, Prédio 43435, 91501-970 \\ Porto Alegre-RS, Brazil. dani_rodrig@yahoo.com.br
}

\begin{abstract}
Comparative description of the immature stages of two very similar leaf footed bugs, Holymenia clavigera (Herbst) and Anisoscelis foliacea marginella (Dallas) (Hemiptera, Coreidae, Anisoscelini). Holymenia clavigera (Herbst, 1784) and Anisoscelis foliacea marginella (Dallas, 1852) (Hemiptera, Coreidae) present a remarkable similarity regarding egg and nymphal morphology. On the contrary, their adult stages are remarkably different. This study describes and compares the immature stages of these two coreid species. Excepting for the last instar and the shape of the hind tibia from third to last instar, nymphs of both species were identical in their gross morphologies and ultrastructures. However, H. clavigera was significantly larger than $A$. foliacea marginella in all stages. Thus, we suggest that these species may have evolved through evolutionary convergence, parsimony between the immature stages after speciation, Müllerian mimicry or genetic drift.
\end{abstract}

KEYwORDs. Anisoscelini; coreids; immature stages; instar identification; passion vines.

Resumo. Descrição comparada dos estágios imaturos de dois coreídeos, Holymenia clavigera (Herbst) e Anisoscelis foliacea marginella (Dallas) (Hemiptera, Coreidae, Anisoscelini). Holymenia clavigera (Herbst, 1784) e Anisoscelis foliacea marginella (Dallas, 1852) (Hemiptera, Coreidae) apresentam uma acentuada semelhança morfológica nos estágios de ovo e ninfa. Entrementes, os adultos são marcadamente distintos. Este estudo descreve e compara os estágios imaturos destas espécies. Excetuando-se a largura da tíbia do terceiro ao quinto instar ninfal, bem como o aspecto e coloração geral das ninfas de quinto ínstars, as ninfas de ambas as espécies foram idênticas em suas morfologias e ultraestruturas. Contudo, H. clavigera foi significativamente maior que A. foliacea marginella em todos os estágios. Desta forma, os imaturos de tais espécies podem ter evoluído através de convergência evolutiva, parcimônia das referidas fases após especiação, mimetismo mileriano ou deriva genética.

Palavras-Chave. Anisoscelini; coreídeos; estágios imaturos; identificação de ínstares; maracujás.

When compared to other insect orders as Lepidoptera or Coleoptera, hemipterans are not well studied in their physiology, ecology and evolution. However, many phytophagous species were described regarding their immature stages. Several of their host plants, in turn, are cultivated for economic purposes (see Schaefer \& Panizzi 2000).

The immature stages of some Coreidae (Heteroptera, Pentatomomorpha) have been described, including nearctic species such as Euthochtha galeator (Fabricius, 1803), Acanthocephala terminalis Dallas, 1852, Archimerus alternatus (Say, 1831) (Yonke \& Medler 1969a, b and c, respectively), Leptoglossus fulvicornis (Westwood, 1842) (Wheeler Jr. \& Miller 1990), as well as others distributed in the tropics as Diactor bilineatus (Fabricius, 1803) (Mariconi 1952a, b), Phthia picta (Drury, 1770) (González 1973; Silva et al. 2001), Leptoglossus zonatus (Dallas, 1852) (Fernandes \& Grazia 1992), and Corecoris (=Spartocera) dentiventris Berg, 1884 (Caldas et al. 1998). Some african coreids had their immatures also briefly described (see Goodchild 1977). Most of these species are considered important from an economic point of view.

Holymenia clavigera (Herbst, 1784) and Anisocelis foliacea marginella (Dallas, 1852) are distributed in southern Brazil and belong to the poorly studied tribe Anisoscelini (but see for example Brailovsky \& Couturier 2003; Brailovsky \& Barrera 2004). There are no studies of the phylogeny of this tribe, and just a few species have their immature stages described (for a revision, see Osuna 1984). The immature stages of $H$. clavigera and A. foliacea marginella remain unknown. These coreids use the same host plants as food resources (Passifloraceae) (Solomon \& Froeschner 1981; Schaefer \& Mitchell 1983), and some individuals were found feeding on both wild (e. g., Passiflora suberosa Linnaeus, 1753) and cultivated species (e. g., Passiflora edulis Sims, 1818) (Lima 1940). Preliminary observations indicate a high coexistence in terms of host plant use and a strong similarity regarding egg and nymphal morphology. In contrast, the adults are remarkably different; $H$. clavigera probably is either a ichneumonid batesian mimic or belongs to a related mimetic ring, while A.foliacea marginella bears morphological features typical of the Anisoscelini tribe, including a remarkable expansion in the hind tibia (see Osuna 1984; Schuh \& Slater 1995; Mitchell 2000).

This study has three major aims. First, it identifies the nymphal instars of $H$. clavigera and $A$. foliacea marginella according to a key for heteropteran instars (Southwood 1956a), which is based on the development of wing pads. Second, the 


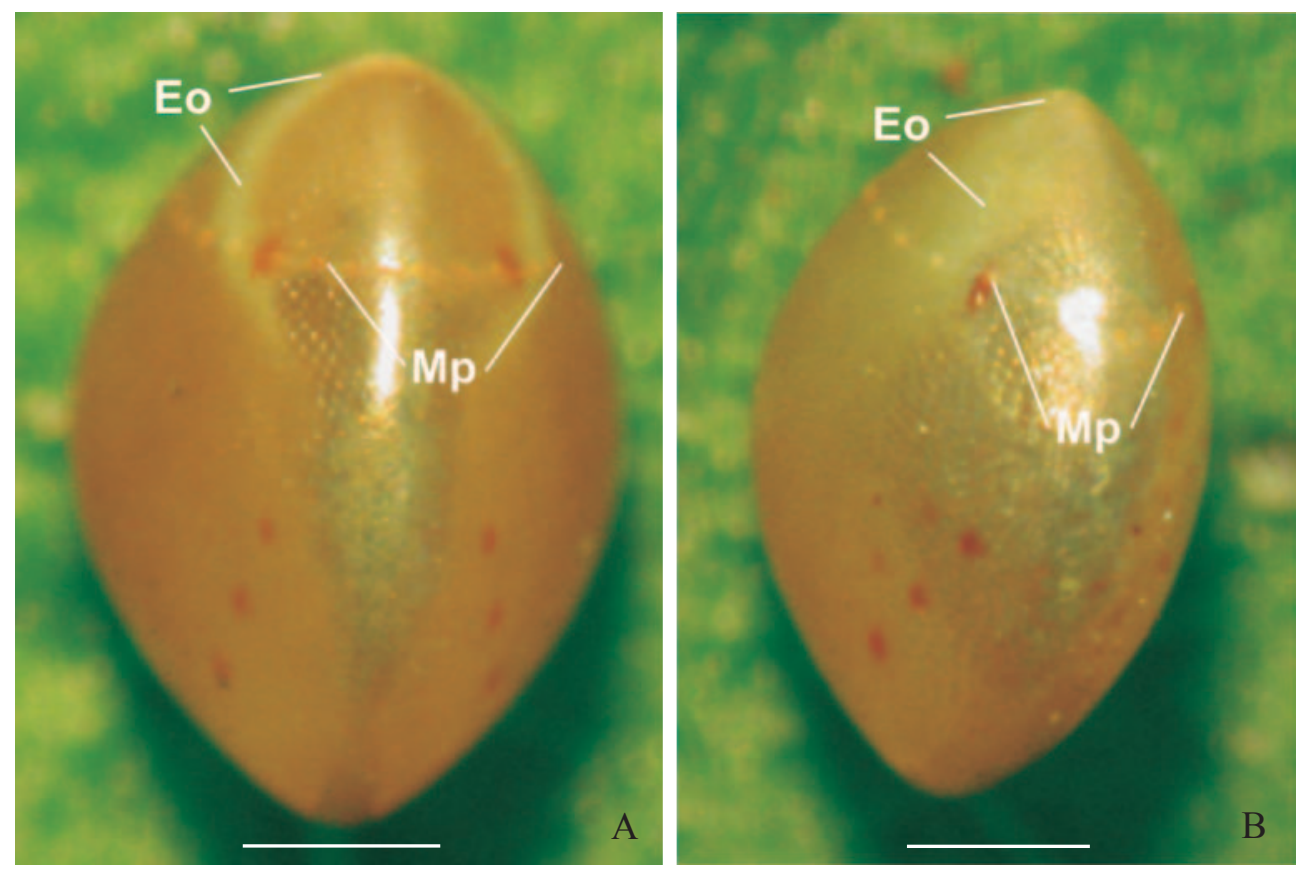

Fig. 1. H. clavigera (A) and A. foliacea marginella (B) eggs. Eo, egg opening; Mp, micropylar processes. Bars $=0.5 \mathrm{~mm}$.

immatures are described and compared by using both light and scanning electron microscopy. Finally, it seeks to add descriptive information about insects associated with passion vines distributed in southern Brazil, which up to now has been restricted to phytophagous lepidopterans as Heliconius erato phyllis (Fabricius, 1775) (Kaminski et al. 2002), Eueides isabella dianasa (Hübner, 1806) (Antunes et al. 2002), and Dione juno juno (Cramer, 1779) (Tavares et al. 2002).

\section{MATERIAL AND METHODS}

Adults of $H$. clavigera and A. foliacea marginella were collected from the vicinity of the Departamento de Zoologia, Universidade Federal do Rio Grande do Sul (UFRGS), as well as from a yard located in an urban area of Porto Alegre County $\left(30^{\circ} 05^{\prime}\right.$ S $\left.51^{\circ} 10^{\prime} \mathrm{W}\right)$, Rio Grande do Sul State (RS). Collected adults were kept separately in cages $(20 \times 20 \times 93 \mathrm{~cm}$; maximum 12 adults/cage) under controlled abiotic conditions (14 hours of light: 10 hours of darkness; $20+2{ }^{\circ} \mathrm{C}$ ). Both species were fed ad libitum with $P$. suberosa shoots, bearing both vegetative (stems, terminal buds and leaves) and reproductive (flower buds, open flowers, green and purple fruits) structures. Tap water placed on Petri dishes with wet cotton was also offered to the adults. P. suberosa shoots came from a cultivation existing at the Departamento de Zoologia, UFRGS, and from plants collected at Fundação Zoobotânica, Porto Alegre County. Shoots were placed in plastic bottles provided with $50 \mathrm{~cm}$ high wooden frame support (maximum three shoots per bottle). Shoots were replaced when wilted. Cages were checked daily, and eggs were collected and placed on Petri dishes, lined with moist filter paper.

To obtain specimens with known ages, newly freshly nymphs were reared in transparent plastic pots $(8.5 \times 8.5 \times 8.5$ $\mathrm{cm}$ ) covered with a mesh cloth. P. suberosa structures, which were disposed in cylindrical pots with water $(3 \times 5 \mathrm{~cm})$, were placed inside the pots to feed the nymphs.

A few specimens were mounted in gelatin jelly to serve as models for the drawings. Additional nymphs ( $\mathrm{n}=20$ / instar / species) were fixed in Dietrich's fluid for additional information when necessary. Nymphs were drawn by using a

Table I. Holymenia clavigera and Anisoscelis foliacea marginella body, antennal and rostrum measurements (mm $+\mathrm{SE})$.

\begin{tabular}{|c|c|c|c|c|c|c|}
\hline \multirow[t]{2}{*}{ Instar } & \multicolumn{2}{|c|}{ body } & \multicolumn{2}{|c|}{ antennae } & \multicolumn{2}{|c|}{ rostrum } \\
\hline & H. clavigera & A. foliacea & H. clavigera & A. foliacea & H. clavigera & A. foliacea \\
\hline I & $3.612+0.072$ & $3.396+0.076$ & $3.872+0.038$ & $3.491+0.035$ & $2.079+0.029$ & $1.749+0.017$ \\
\hline II & $5.793+0.159$ & $5.295+0.098$ & $5.987+0.070$ & $5.876+0.059$ & $4.192+0.081$ & $3.403+0.066$ \\
\hline III & $8.756+0.121$ & $7.843+0.158$ & $7.833+0.094$ & $7.612+0.095$ & $5.702+0.073$ & $4.474+0.052$ \\
\hline $\mathrm{IV}$ & $11.778+0.196$ & $10.499+0.190$ & $9.579+0.102$ & $9.703+0.083$ & $7.105+0.106$ & $5.793+0.070$ \\
\hline V & $14.268+0.195$ & $13.073+0.338$ & $13.097+0.106$ & $13.629+0.141$ & $8.947+0.156$ & $7.321+0.078$ \\
\hline
\end{tabular}



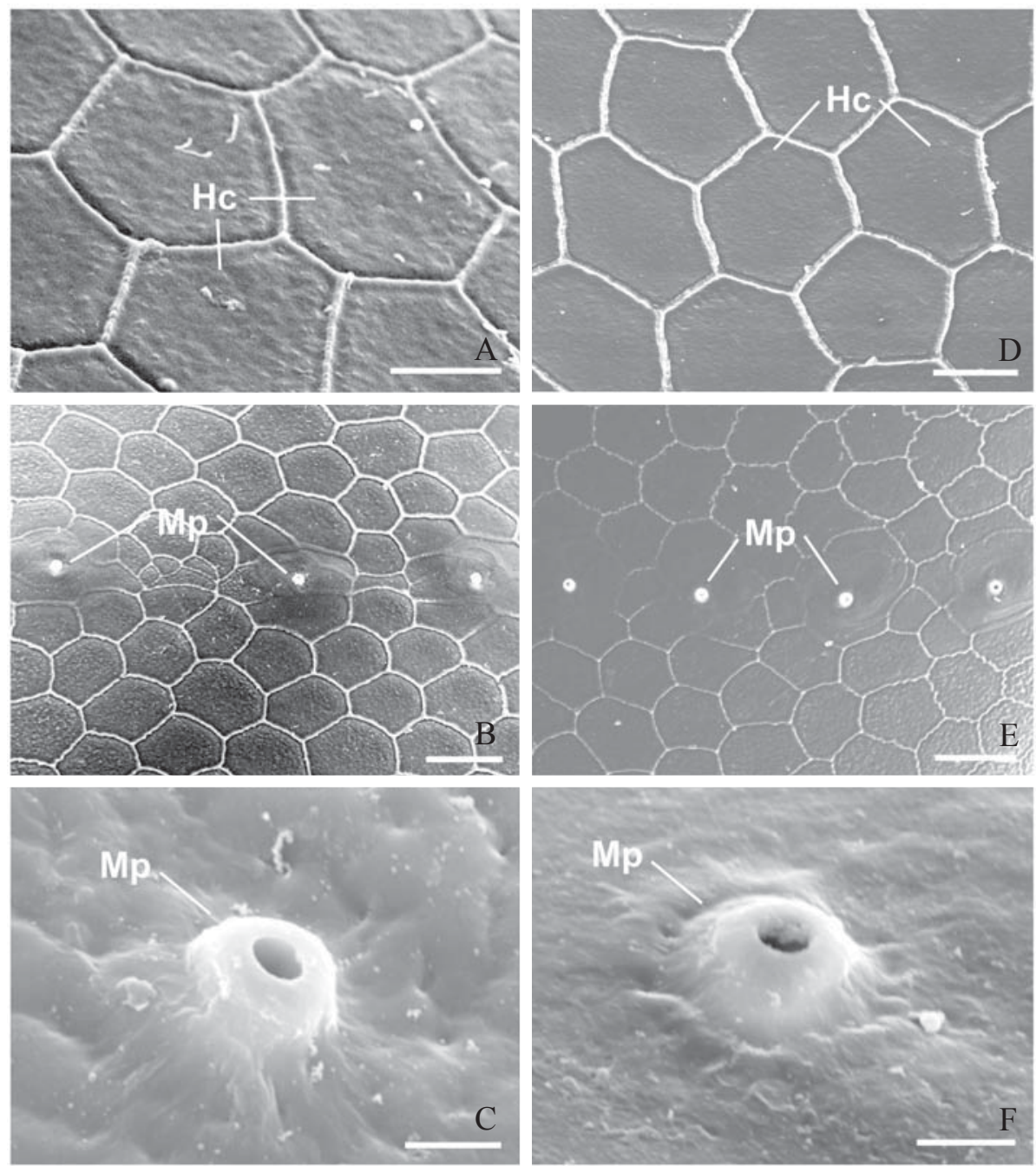

Fig. 2. Chorionic ultrastructure of $H$. clavigera and A. foliacea marginella eggs (figures A, B e C for H. clavigera and D, E, and F for A. foliacea marginella, respectively) under scanning electron microscopy. Hc, hexagonal and heptagonal cells; Mp, micropylar processes. Bars $=20,50$ e $5 \mathrm{~mm}$ for both species, respectively.

stereomicroscope $\left(\right.$ Spencer $\left.^{\circledR}\right)$ equipped with an ocular grid. The drawings were then water color painted, the corresponding colors being defined through focal observations and photographs of living specimens.

Additional fixed eggs and nymphs were observed through scanning electron microscopy. They were critical point dried in a Bal-tec $-\mathrm{CPD} 030^{\circledR}$ equipment and attached with double Scotch ${ }^{\hat{a}}$ stick tape to aluminum stubs. Then, they were goldcoated with a Bal-tec $-\mathrm{SCD} 050^{\circledR}$ sputter coater, examined and photographed in a JEOL $5800^{\circledR}$ scanning electron microscope. To characterize trichobothria number, location, and arrangement in the first instar nymphs, five specimens were colored with congo red for $30 \mathrm{~min}$ and then examined with a Leica $^{\circledR}$ stereomicroscope (100x).

H. clavigera and A. foliacea marginella eggs were preserved with Dietrich's fluid $(\mathrm{n}=20)$ and then measured in relation to their height and maximum diameter. Such measurements were used to estimate egg volume through the following formula: $\mathrm{pr}^{2} \mathrm{~h}$, where $r=$ radius; $h=$ height. Eggs were measured with a stereomicroscope (Wild ${ }^{a}$ ) equipped with a micrometric scale. Egg development time was obtained through daily observations of eggs placed in Petri dishes, lined with moist filter paper. The Petri dishes were kept in a large laboratory chamber (abiotic conditions described above).

Body (from tylus to last abdominal segment), antennae (sum of lengths of the four antennomeres) and rostrum length measurements (from labrum to mandibles) were obtained from those specimens fixed with Dietrich's fluid ( $n=20$ / instar / species). All measurements are presented as mean + standard error. Egg data were evaluated for normality and homoscedasticity of variances through Kolmogorov-Smirnov and Bartlett tests. Then, egg measurements were compared statistically by using Student $t$ test or Mann-Whitney U test (Sokal \& Rohlf 1995; Zar 1999). Alpha $=0.05$ was adopted for all statistical tests. 

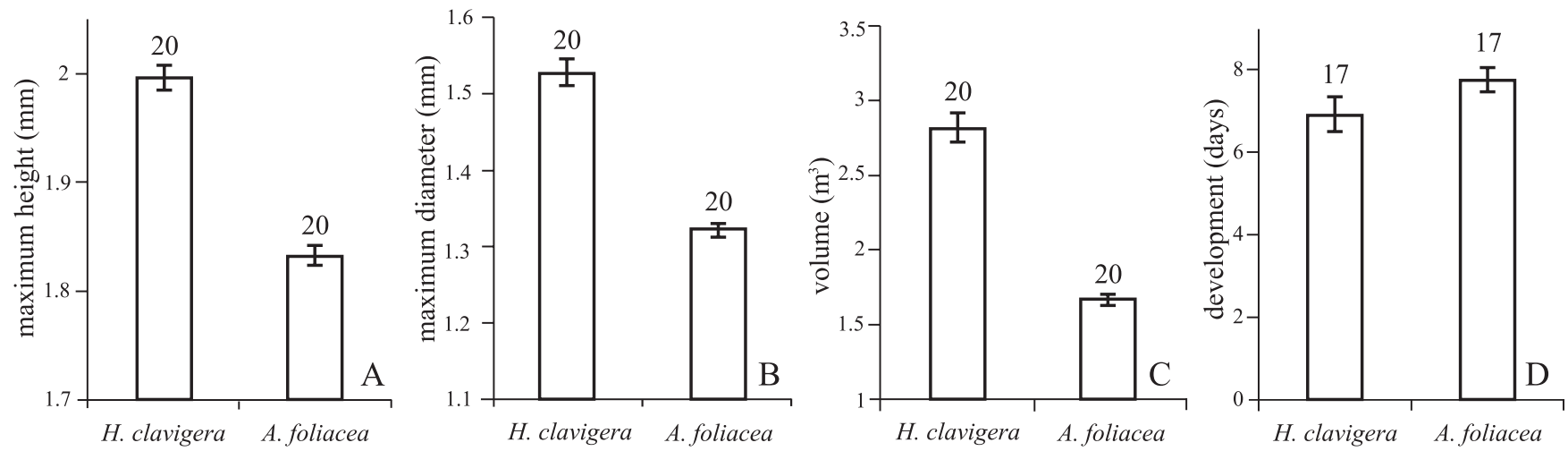

Fig. 3. Maximum height (A), maximum diameter (B), volume (C) and development time (D) of H. clavigera and A. foliacea marginella eggs (mean + standard error). Numbers above bars indicate number of eggs used to estimate the corresponding parameter.

\section{RESULTS}

\section{Egg}

Holymenia clavigera. Gold color just after deposition, turning to brown later in the development (Figure 1A). Subspherical shape; underside flat, where the egg is attached to the oviposition site. Egg attached to the surface by an unknown structure. Upperside convex, where embrionic structures became visible by transparency close to nymph eclosion. Chorion mainly in a hexagonal sculpturing, varying from 5 to 7 -sided (Figs. 2A, 2B). Upperside with micropylar processes and egg opening (Figs. 1A, 2B, 2C). Micropylar processes simple, flat, circular, and their row crossed the upper portion of the egg opening. Micropylar processes: $28.80+$ 0.70 ( 23 to 36 processes/egg). Maximum height: $1.998+0.011$ $\mathrm{mm}$; maximum diameter: $1.528+0.017 \mathrm{~mm}$; volume: $2.820+$ $0.095 \mathrm{~cm}^{3}$ (Figs. 3A-C).

Egg development time: $6.94+0.424$ days (Fig. 3D). After the third day, it is possible to see embryo eyes, rostrum and legs by transparency (Fig. 1A).

Anisoscelis foliacea marginella. Morphological characteristics as described for $H$. clavigera (Figs. 1B, 2D, 2E). Micropylar processes: $23.55+0.46$ (20 to 28 per egg) (Figs. 1B, 2E, 2F). Maximum height: $1.834+0.009 \mathrm{~mm}$; maximum diameter: $1.321+0.009 \mathrm{~mm}$; volume, $1.667+0.037 \mathrm{~cm}^{3}$ (Figs. 3A-C). Development time: $7.76+0.303$ days (Fig. 3D). When compared to $H$. clavigera, all $A$. foliacea marginella egg measures are significantly smaller (Student $t$ test to maximum height: $\mathrm{t}=11.289 ; P<0.0001-$ Mann-Whitney $\mathrm{U}$ test to maximum diameter and volume: $\mathrm{U}=400.00 ; P<0.0001$ for both parameters). Egg development time does not differ between species (Mann-Whitney $\mathrm{U}$ test, $\mathrm{U}=182.50 ; P=0.1926$ ).

\section{Nymphs}

For all instars regarding both species, morphometric information is presented on table I.

According to Rodrigues (2003), H. clavigera is larger than A. foliacea marginella in relation to body and rostrum lengths.

\section{Instar I}

Holymenia clavigera. Body oval (Fig. 4A). Head green; antennae elongate, ranging from brown to black. Antennomeres two and three with a longitudinal crista. Red eyes. Juga longer than tylus; just a few individuals show juga and tylus with the same length. Juga triangulate with thin tips. Ecdysial cleavage line dark-green to brown. Rostrum extending to the first abdominal segment. Groups of elongate setae close to ecdysial cleavage line, eyes and jugae.

Thorax green; lateral parts tending to be brown. Legs flat and dark-brown. Tarsi with two tarsomeres; pretarsal claws with two pulvilli. Meso- and metathorax each bearing a pair of spiracles (Snodgrass 1935). Meso- (Fig. 5A) and metathorax undistinguishable, being wing pads not detected at this instar.

Abdomen green, bearing ten segments; two scent glands on margins of terga IV-V and V-VI (Yonke 1991), each gland bearing two lateral openings. Groups of elongate setae close to gland openings. Circular spiracles from segments II to VIII, latero-ventral located. Ventrally, three trichobothria on median of ${ }^{1 / 3}$ sterna III and IV, three on lateral ${ }^{1 / 3}$ of sterna $V$ and VI, and two on lateral $1 / 3$ of sternum VII. There is some variability among individuals regarding trichobothria arrangement within a given segment. Trichobothria number and location according to what Schaefer (1975) presented for Coreidae, as those described for L. zonatus (Fernandes \& Grazia 1992), C. dentiventris (Caldas et al. 1998), and P. picta (Silva et al. 2001).

Anisoscelis foliacea marginella. All characteristics as described for H. clavigera at this instar (Figs. 4F, 5F).

\section{Instars II - IV}

Holymenia clavigera. Body more elongate than oval in the second instar (Fig. 4B), and elongate in third and fourth instars (Figs. 4C, 4D). All antennomeres with a longitudinal crista. In the second instar, wing pads in a vestigial form; anterior wing pads much smaller than mesothorax length (Fig. 


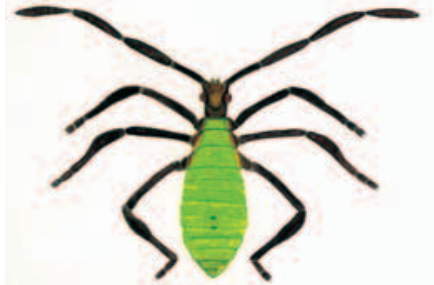

A

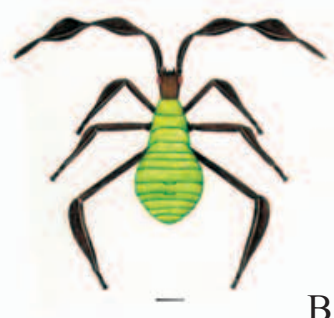

B
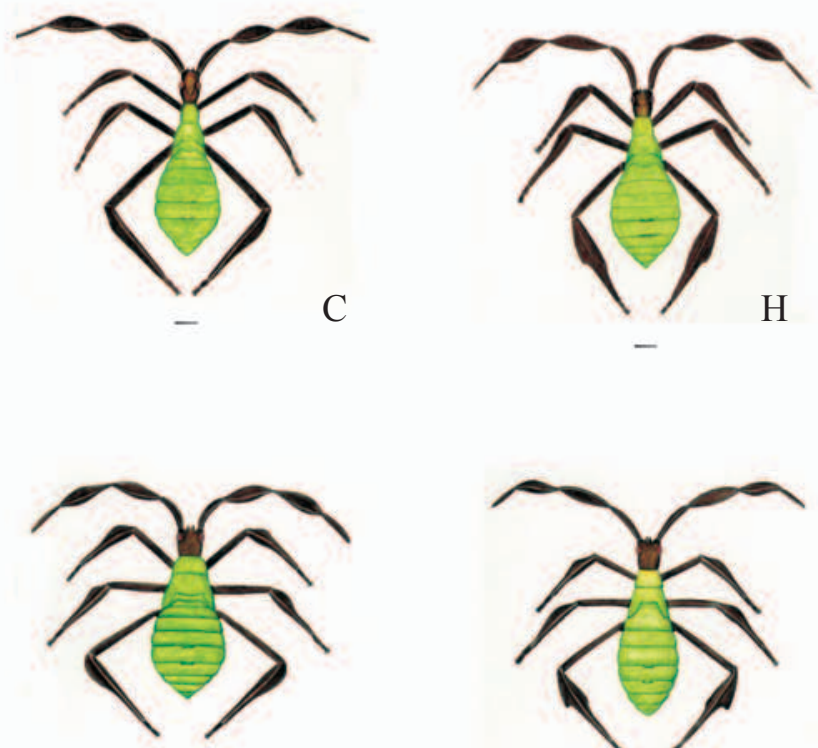

$\mathrm{D}$

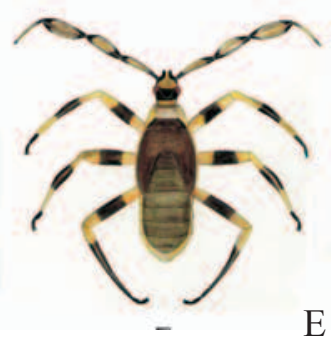

E
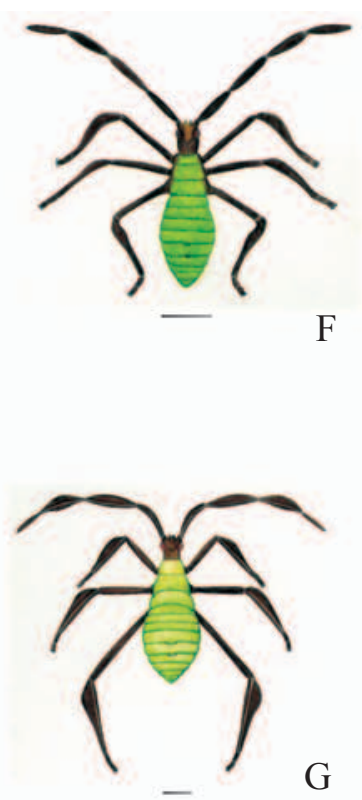

G

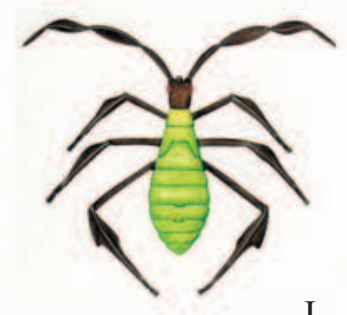

I

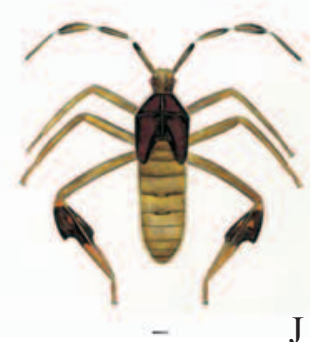

Fig. 4. Dorsal view of $H$. clavigera (figures A to $\mathrm{E}-$ from first to fifth instar, respectively) and A. foliacea marginella (figures $\mathrm{F}$ to $\mathrm{J}$ - from first to fifth instar, respectively) nymphs. Bars $=1 \mathrm{~mm}$.
5B). Anterior wing pads covering less than $10 \%$ of metathorax. In the third instar, meso- and metathorax bearing visible wing pads; tips of the mesothorax covering about half of the metathorax (Fig. 5C). In the fourth instar, tips of the anterior wing pads do not extend beyond the tips of the posterior wing pads, covering almost $90 \%$ of them (Fig. 5D). Other characteristics as described for the first instar.

Anisoscelis foliacea marginella. Hind tibia expansion became visible in the third instar (Fig. 6H). In the fourth instar, hind tibia dilatation became more expanded (Fig. 6I). Other characteristics as described for $H$. clavigera at the corresponding instars (Figs. 4G, 4H, 4I, 5G, 5H, 5I).

\section{Instar V}

Holymenia clavigera. Body elongate (Fig. 4E). Antennomeres brownish-yellow bearing a brown margin. Head yellowish brown with a central brown band.

Pronotum and anterior wing pads brown with a yellow margin. Pro- and mid legs bearing femur and tibia yellowishorange with a central dark-brown band. Hind tibia with a yellowish-orange band in the proximal part, as well as a large brown band at the distal part. Tarsi and pretarsi dark-brown. Tips of the anterior wing pads extending beyond the tips of the posterior pads (Fig. 5E).

Abdomen brownish-green, bearing yellow margins. Other characteristics as in the fourth instar.

Anisoscelis foliacea marginella. Antennomeres ochre; margins tending to black. Head ochre; jugae and tylus slighter than head.

Pronotum, anterior and posterior wing pads brown bearing violaceous bands. Margins of pronotum and anterior wing pads denticulated. Anterior and mid legs ochre bearing several transversal orange bands. Hind tibia with a brown band close to its proximal part. At this part, tibia reaches its largest width (Figs. 6A-J).

Abdomen ochre with margin whitish-yellow. Other characteristics as in the fourth instar (Figs. 4J, 5J).

\section{DISCUSSION}

H. clavigera and A. foliacea marginella eggs are identical in coloration, shape, chorion sculpturing, micropylar processes, egg opening and development time, being only different in size. The literature regarding eggs of Anisoscelini is scarce, excepting for Leptoglossus and Narnia (see Mitchell 2000), and no pattern was found for Coreidae in general (see Southwood 1956b; Cobben 1968; Hinton 1981). Moreover, there is no clear information about the role of the micropylar processes in hemipteran eggs. These structures may be involved in egg gas exchange, reproduction or both (e. g., Bundy \& McPherson 2000). It is known that insect eggs bear respiratory structures named aeropyles, which may be associated to plastrons. Micropyles, in turn, are different 

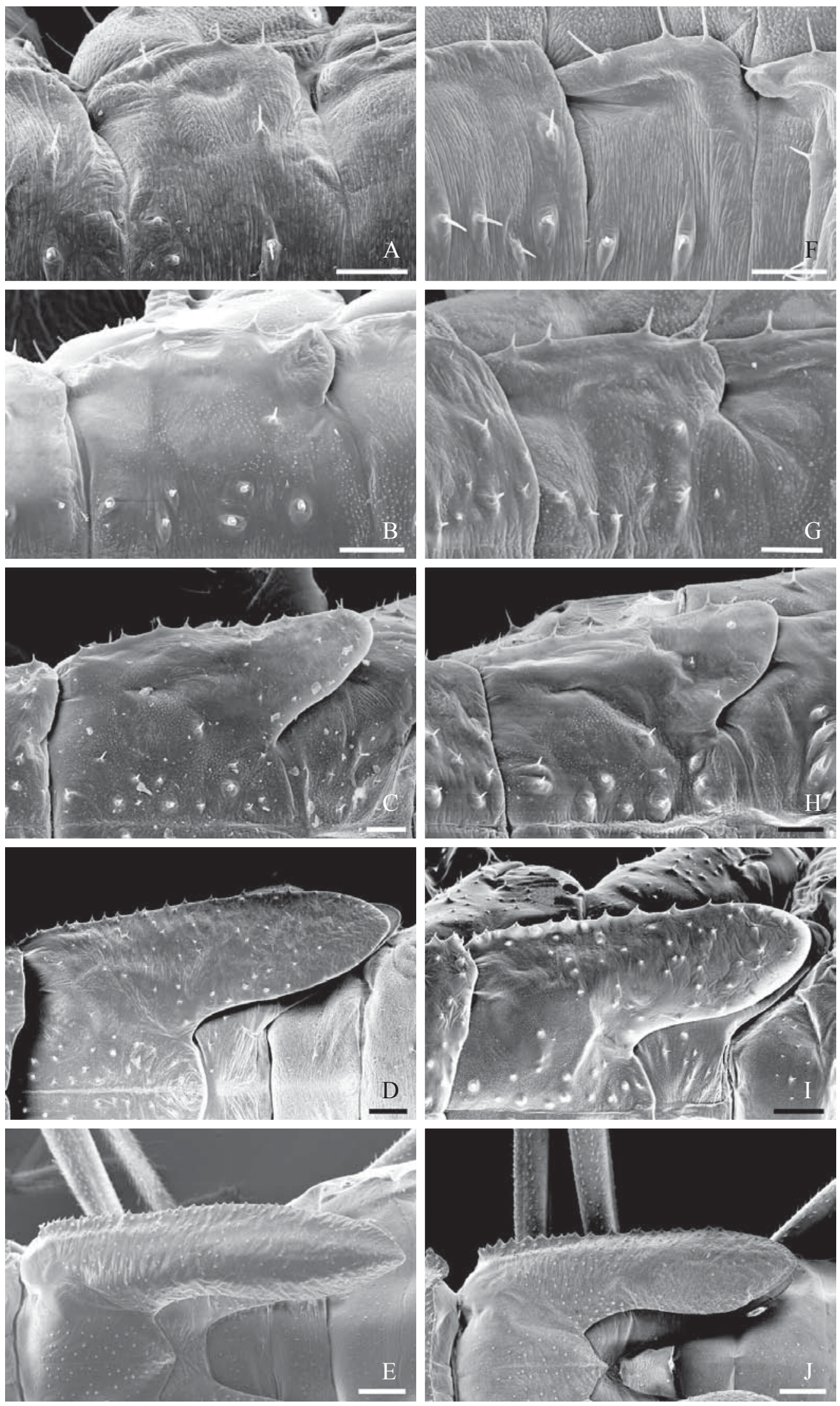

Fig. 5. Anterior wing pads of $\mathrm{H}$. clavigera (figures A to $\mathrm{E}$ - from first to fifth instar, respectively) and A. foliacea marginella (figures $\mathrm{F}$ to $\mathrm{J}$ - from first to fifth instar, respectively) under scanning electron microscopy. Bars $=100,100,100,200,500 \mathrm{~mm}$ - first to fifth instar for both species, respectively. 

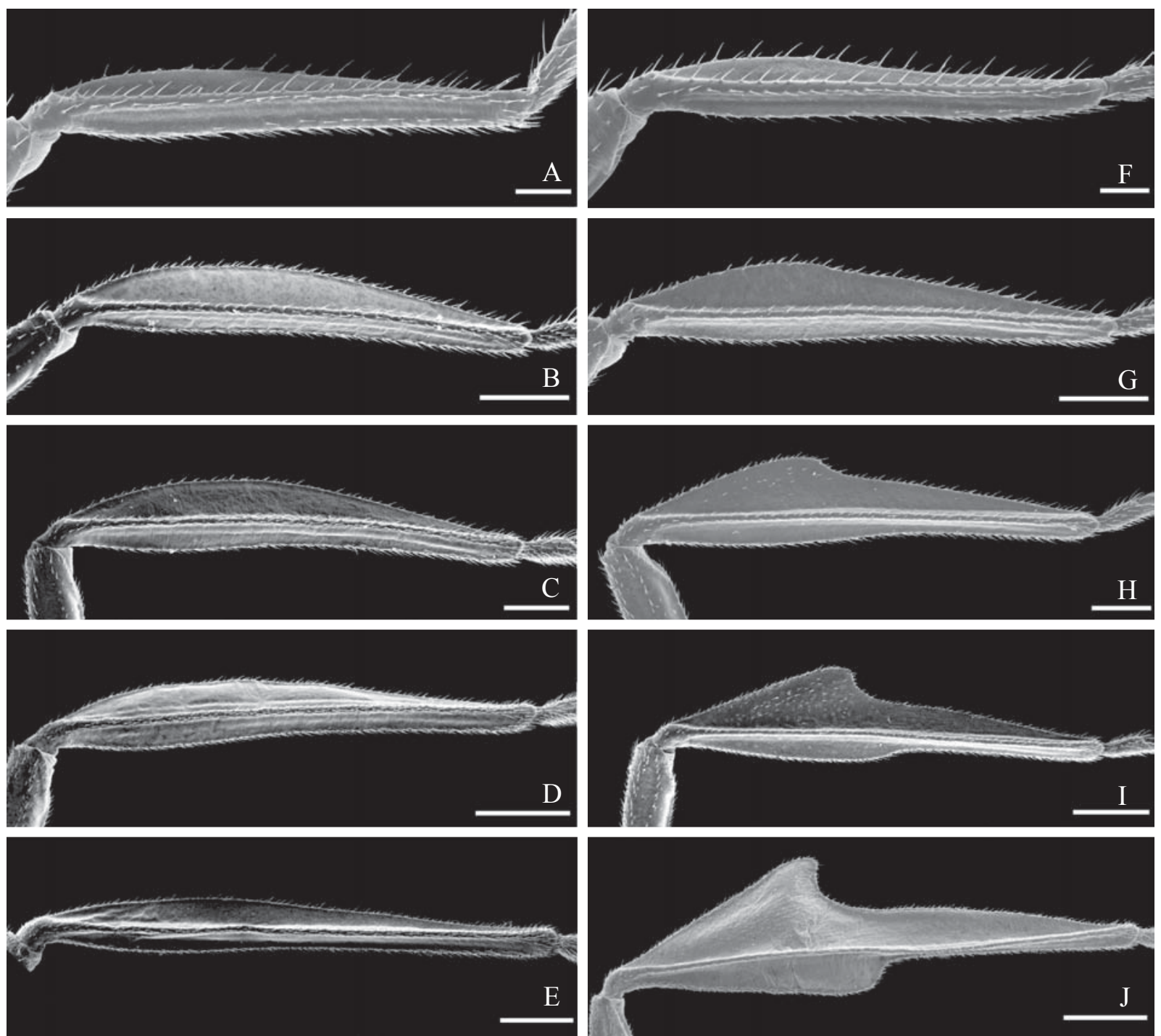

Fig. 6. Posterior view of the right hind tibia of $H$. clavigera (figures A to $\mathrm{E}-$ first to fifth instar, respectively) and A. foliacea marginella (figures $\mathrm{F}$ to $\mathrm{J}$ - first to fifth instar, respectively) under scanning electron microscopy. Bars $=200,500,500 \mathrm{~mm} ; 1$ and $1 \mathrm{~mm}-$ from first to fifth instar for both species, respectively.

structures that allow egg fertilization (see Hinton 1981). There is the possibility that the micropylar processes can act both as respiratory and reproductive structures in this case, which needs further investigation.

This work confirms the applicability of the heteropteran instar identification key proposed by Southwood (1956a), since all instars showed wing pad development accordingly. Only a few studies have considered this key to identify heteropteran instars. No examples were found in coreid species, but in Tingidae (e. g., Sheeley \& Yonke 1977).

Immatures of both species are identical in their gross morphologies and color. Although we have not described their ultrastructures in detail, we did not find any differences between species at that level. Additional studies showed that both coreids also present similarities in terms of host plant preference and performance, which can explain in part the strong morphological similarity (Rodrigues 2003). The only morphological differences between $H$. clavigera and $A$. foliacea marginella immatures here detected are the last instar nymphs and the shape of the hind tibia from third to last instar. Besides, hind tibia shape in early instars and overall size play an important role regarding species differentiation. H. clavigera is significantly larger than A. foliacea marginella in all stages, and their ontogenetic trajectories are significantly different. Also, it has been demonstrated through geometric morphometrics that hind tibia shape of these coreids is significantly different since second instar (Rodrigues 2003).

To our knowledge, this is the first study that shows a total morphological resemblance between immatures of different insect species at both general and ultrastructural levels. This finding leads to additional factors that must to be taken into account in further comparative studies. It is known that many immature forms or species show great morphological similarities in the early stages. The total resemblance between species 
may be more common in the nature due to parsimony, absence of selective pressures, evolutionary convergence, mimicry or genetic drift. Such hypotheses should be better explored in studies regarding evolutionary development of related species, which consider both descriptive and evolutionary approaches.

Acknowledgements. The authors wish to thank José A.M. Fernandes and Jocélia Grazia for species identification, and for their helpful orientation regarding hemipteran literature and terminology. Also, to Lucas A. Kaminski for painting the nymphs and José F.R. Amato for egg photographs. We are also grateful to Centro de Microscopia Eletrônica / UFRGS, especially to Francis F. Darsie and Moema Q. Vieira. We are specially grateful to Carl W. Schaefer (University of Connecticut), and two anonymous reviewers, for critically reading the manuscript. This is contribution number 454 of the Departamento de Zoologia, Universidade Federal do Rio Grande do Sul.

\section{REFERENCES}

Antunes, F. F.; A. O. Menezes Jr.; M. Tavares \& G. R. P. Moreira. 2002. Morfologia externa dos estágios imaturos de heliconíneos neotropicais I. Eueides isabella dianasa (Hübner, 1806). Revista Brasileira de Entomologia 46: 601-610.

Brailovsky, H. \& E. Barrera. 2004. Six new species of Leptoglossus Guerin (Hemiptera: Heteroptera: Coreidae: Coreinae: Anisoscelini). Journal of the New York Entomological Society 112: 56-74.

Brailovsky, H. \& G. Couturier. 2003. A new species of Leptoglossus (Heteroptera: coreidae: anisoscelini) associated with the Amazonian palm Mauritia flexuosa (Arecaceae: lepidocaryeae) in Peru. Entomological News 114: 18-22.

Bundy, C. S. \& R. M. McPherson. 2000. Morphological examination of stink bug (Hemiptera: Pentatomidae) eggs on cotton and soybeans, with a key to genera. Annals of the Entomological Society of America 93: 616-624.

Caldas, B. H. C.; L. R. Redaelli \& L. M. G. Diefenbach. 1998. Descrição dos estágios imaturos de Corecoris dentiventris Berg (Hemiptera: Coreidae). Anais da Sociedade Entomológica do Brasil 27: 405-412.

Cobben, R. H. 1968. Evolutionary trends in Heteroptera. Part I: Eggs, architecture of the shell, gross embryology and eclosion. Wageningen, Centre for Agricultural Publishing and Documentation, $475 \mathrm{p}$.

Fernandes, J. A. M. \& J. Grazia. 1992. Estudo dos estágios imaturos de Leptoglossus zonatus (Dallas, 1852) (Heteroptera-Coreidae). Anais da Sociedade Entomológica do Brasil 21: 179-188.

González, H. E. S. 1973. Biologia de Phthia picta (Drury) (Hemiptera, Coreidae). Fitotecnia Latino Americana 9: 3-9.

Goodchild, A. J. P. 1977. Bionomics, aggregated feeding behaviour, and colour variations in the sap-sucking bug Mygdonia tuberculosa Sign. Review of African Zoology 91: 1032-1041.

Hinton, H. E. 1981. Biology of insect eggs. 3v. Oxford, Pergamon Press, $1125 \mathrm{p}$.

Kaminski, L. A.; M. Tavares; V. G. Ferro \& G. R. P. Moreira. 2002. Morfologia externa dos estágios imaturos de heliconíneos neotropicais. III. Heliconius erato phyllis (Fabricius) (Lepidoptera, Nymphalidae, Heliconiinae). Revista Brasileira de Zoologia 19: $977-993$

Lima, A. C. 1940. Insetos do Brasil: Hemípteros. Tomo II. Rio de Janeiro, Escola Nacional de Agronomia, 351 p.

Mariconi, F. A. M. 1952a. O percevejo do maracujá Diactor bilineatus (Fabr., 1803). O Biológico 18: 116-120.

Mariconi, F. A. M. 1952b. Contribuição para o conhecimento do Diactor bilineatus (Fabricius, 1803) (Hemiptera-Coreidae), praga do

Received 11.II.2004; accepted 23.X.2004 maracujazeiro (Passiflora spp.). Arquivos do Instituto Biológico 21: $21-42$.

Mitchell, P. L. 2000. Leaf-footed bugs (Coreidae), p. 337-403. In: C. W. Schaefer \& A. R. Panizzi (eds.). Heteroptera of economic importance. Boca Raton, CRC Press, 828 p.

Osuna, E. 1984. Monografía de la tribu Anisoscelini (Hemiptera, Heteroptera Coreidae) I. Revisión genérica. Boletín de Entomología Venezolana 3: 77-148.

Rodrigues, D. 2003. Descrição, trajetórias ontogenéticas de Holymenia clavigera (Herbst, 1784) e Anisoscelis foliacea marginella (Dallas, 1852) (Hemiptera: Coreidae) e interação com três espécies de Passifloraceae. Unpublished Thesis. Porto Alegre, UFRGS, $127 \mathrm{p}$.

Schaefer, C. W. 1975. Heteropteran trichobothria (Hemiptera: Heteroptera). International Journal of Insect Morphology \& Embryology 4: 193-264.

Schaefer, C. W. \& P. L. Mitchell. 1983. Food plants of the Coreidoidea (Hemiptera: Heteroptera). Annals of the Entomological Society of America 76: 591-615.

Schaefer, C. W. \& A. R. Panizzi. 2000. Economic importance of heteroptera: a general view, p. 3-8. In: C. W. Schaefer \& A. R. Panizzi (eds.). Heteroptera of economic importance. Boca Raton, CRC Press, 828 p.

Schuh, R. T. \& J. A. Slater. 1995. True bugs of the world (Hemiptera: Heteroptera): classification and natural history. Ithaca, Cornell University Press, $336 \mathrm{p}$.

Sheeley, R. D. \& T. R. Yonke. 1977. Immature stages and biology of Atheas austroriparius and Leptoypha costata (Hemiptera: Tingidae). Annals of the Entomological Society of America 70: 603614.

Silva, R. A.; P. S. Flores \& G. S. Carvalho. 2001. Descrição dos estágios imaturos de Phthia picta (Drury) (Hemiptera: Coreidae). Neotropical Entomology 30: 253-258.

Snodgrass, R. E. 1935. Principles of insect morphology. Ithaca, Cornell University Press, $667 \mathrm{p}$.

Sokal, R. R. \& F. J. Rohlf. 1995. Biometry. $3^{\text {rd }}$ ed. New York, Freeman, $887 \mathrm{p}$.

Solomon, J. C. \& R. C. Froeschner. 1981. Notes on food resources and behavior of the family Coreidae (Hemiptera) in a semi-deciduos tropical forest. Proceedings of the Entomological Society of Washington 83: 428-431.

Southwood, T. R. E. 1956a. A key to determine the instar of an heteropterous larva. The Entomologist 89: 220-222.

Southwood, T. R. E. 1956b. The structure of the eggs of the terrestrial heteroptera and its relationship to the classification of the group. Transactions of the Royal Entomological Society of London 108: 163-221.

Tavares, M.; L. A. Kaminski \& G. R. P. Moreira. 2002. Morfologia externa dos estágios imaturos de heliconíneos neotropicais II. Dione juno juno (Cramer) (Lepidoptera, Nymphalidade, Heliconiinae). Revista Brasileira de Zoologia 19: 961-976.

Wheeler Jr., A. G. \& G. L. Miller. 1990. Leptoglossus fulvicornis (Heteroptera: Coreidae), a specialist on magnolia fruits: seasonal history, habitats, and descriptions of immatures stages. Annals of the Entomological Society of America 83: 753-765.

Yonke, T. R. 1991. Order Hemiptera, p. 22-65. In: F. W. Stehr (ed.). Immature insects. Vol. II. Dubuque, Kendall / Hunt Publishing Company, $975 \mathrm{p}$.

Yonke, T. R. \& J .T. Medler. 1969a. Description of immature stages of Coreidae. 1. Euthochtha galeator. Annals of the Entomological Society of America 62: 469-473.

Yonke, T. R. \& J .T. Medler. 1969b. Description of immature stages of Coreidae. 2. Acanthocephala terminalis. Annals of the Entomological Society of America 62: 474-476.

Yonke, T. R. \& J .T. Medler. 1969c. Description of immature stages of Coreidae. 3. Archimerus alternatus. Annals of the Entomological Society of America 62: 477-480.

Zar, J. H. 1999. Biostatistical analysis. $4^{\text {th }}$ ed. Upper Saddle River, Prentice Hall, 663 p. 